L. Koroliova

Л. В. Корольова

Л. В. Королёва

Oles Honchar Dnipro National University

Дніпровський національний університет імені Олеся Гончара

Днепровский национальный университет имени Олеся Гончара

\title{
PROFESSIONAL TRAINING OF FOREIGN LANGUAGE TEACHERS: TODAY'S GLOBAL REALITIES
}

\author{
ОСОБЛИВОСТІ ПРОФЕСІЙНОЇ ПІДГОТОВКИ ВЧИТЕЛІВ \\ ІНОЗЕМНИХ МОВ: ГЛОБАЛЬНІ РЕАЛІЇ СУЧАСНОСТІ
}

\section{ОСОБЕННОСТИ ПРОФЕССИОНАЛЬНОЙ ПОДГОТОВКИ УЧИТЕЛЕЙ ИНОСТРАННЫХ ЯЗЫКОВ: ГЛОБАЛЬНЫЕ РЕАЛИИ СОВРЕМЕННОСТИ}

This paper addresses to common problems of training a generation of students with clip thinking, fluent in IT-technologies and modern gadgets. This generation grew up surrounded by constantly improving digital technologies, accompanied by the media, which constantly provides the viewer with information mainly of entertaining or intimidating nature (talk shows, sitcoms, TV shows, contests, games, constantly interrupted by commercials, news, etc.). As a result, the brain is rebuilt, adapting to reality, and a new type of thinking arises - the socalled 'Clip thinking', which is characterized by fragmentation, non-linearity, emotionality, quick switching from one topic to another, illogicality. In accordance with this, the features of students' thinking, over the years of rapid technological progress and the development of the media, have acquired new characteristics. Unlike the previous generation with digital thinking, which is characterized by rationality, ability to think algorithmically and multitasking, students with clip thinking need new approaches in teaching and preparing them for future professional activities. Given the above, it is necessary to create a new teaching technology that will contribute to the quality training of a new generation of future foreign language teachers.

Keywords: clip thinking, linear thinking, future teachers, teaching technology, foreign languages.

Розглянуто особливості професійної підготовки покоління студентів 3 кліповим мисленням, які вільно володіють IT-технологіями та сучасними гаджетами. Це покоління росло в оточенні цифрових технологій, які постійно удосконалюються, в супроводі ЗМІ, що постійно представляють глядачеві інформацію, в основному, розважального або страхітливого характеру (ток-шоу, сіткоми, серіали, конкурси, ігри, новини і т.Д) яка постійно переривається рекламними роликами. В результаті мозок перебудовується, адаптуючись до реальності, і виникас новий тип мислення - так зване «кліпове мислення» ('Clip thinking'), якому характерні фрагментарність, нелінійність, емоційність, швидке переключення з однісї теми на іншу, алогічність. Відповідно до цього, особливості мислення студентів, за роки стрімкого технічного прогресу і розвитку 3МІ набули нових характеристик. На відміну від попереднього покоління з цифровим мисленням, якому притаманні раціональність, алгоритмічность і багатозадачність, студенти 3 кліповим мисленням потребують нових підходів у навчанні та підготовці їх до майбутньої професійної діяльності. 3 огляду на вищесказане, необхідно створення нової технології навчання, яка буде сприяти якісній підготовці нового покоління майбутніх вчителів іноземних мов.

Ключові слова: кліпове мислення, лінійне мислення, майбутні вчителі, технологія навчання, іноземні мови.

(C) Koroliova L., 2020 
Рассмотрены особенности профессиональной подготовки поколения студентов с клиповым мышлением, свободно владеющих IT-технологиями и современными гаджетами. Это поколение росло в окружении постоянно совершенствующихся цифровых технологий, в сопровождении СМИ, которые постоянно представляют зрителю информацию, в основном, развлекательного или устрашающего характера (ток-шоу, ситкомы, сериалы, конкурсы, игры, новости и т.д) постоянно прерывающуюся рекламными роликами. В итоге мозг перестраивается, адаптируясь к реальности, и возникает новый тип мышления - так называемое «клиповое мышление» ('Clip thinking'), которому характерны фрагментарность, нелинейность, эмоциональность, быстрое переключение с одной темы на другую, алогичность. В соответствии с этим, особенности мышления студентов за годы стремительного технического прогресса и развития СМИ приобрели новые характеристики. В отличие от предыдущего поколения с цифровым мышлением, которому присущи рациональность, алгоритмичность и многозадачность, студенты с клиповым мышлением нуждаются в новых подходах в обучении и подготовке их к будущей профессиональной деятельности. Учитывая вышесказанное, необходимо создание новой технологии обучения, которая будет способствовать качественной подготовке нового поколения будущих учителей иностранных языков.

Ключевые слова: клиповое мышление, линейное мышление, будущие учителя, технология обучения, иностранные языки.

In the modern world, where digital technologies are an integral part of human activity, it will be increasingly difficult to meet students in the libraries of higher educational institutions reading scientific literature. The generation that grew up in the late 90 s of the last century - the beginning of the XX century, surrounded by constantly improving digital technologies, accompanied by the media, which constantly provides the viewer with information that is mainly entertaining or intimidating (talk shows, sitcoms, TV shows, contests, games that are constantly interrupted commercials, news, etc.), quickly rebuilt and adapted to the reality of the modern world. As a result, a new type of thinking emerged the so-called 'Clip thinking', which is characterized by fragmentation, non-linearity, emotionality, quick switching from one topic to another, illogicality. In accordance with this, the features of students' thinking, over the years of rapid technological progress and the development of the media, have acquired new characteristics. They are quite negative in nature and can lead to more complexes, even on a physical level, consequences: ADHD (Attention Deficit Disorder), virtual and Internet addiction, laziness of the mind, loss of ability to concentrate, superficiality of knowledge. If 30 years ago the printed word was the main source of information, nowadays it has a serious competitor; the virtual source is the Internet. This alternative source allows you to get a huge amount of information in a short period of time, i. e. in seconds. This means that most people spend only one second on a website before leaving, and often because they cannot wait for the website to load. They look for information, click on it and then leave because it does not come fast enough. This is acompletely alien of affairs when you compare it to the way we searched for information 30 years ago [7]. In those days, it was necessary to find a book or public library with the necessary information, and then had to plunge into books to explore a topic of interest. If you look at the desktop of a teenager's PC, you can find at least 5 tabs open in the browser. He or she can simultaneously watch a favorite series, browse news pages and communicate on the phone in one of the social networks. Bright colors, fast gameplay, loud sound effects, lead to chaos in thoughts, desires and actions. As a result of the digitalization of society, linear thinking gives way to clip thinking.

The aim of this study is to examine the peculiarities of professional training of future teachers of foreign languages with clip thinking. The term «clip thinking» appeared in the late $90 \mathrm{~s}$ of the twentieth century. However, its appearance was predicted in the $60 \mathrm{~s}$ 
of the last century by the philosopher M. McLuhan, at a time when a limited number of people knew about the existence of computers. He suggested that the development of electronic means of communication brings human thinking back to the pre-text era and the linear sequence of signs ceases to be the basis of culture [2]. And in the 90s, some scientists note the gradual replacement of linear thinking with nonlinear and that logical thinking is losing its importance [4].

The linearity of thinking is characterized by consistency, i. e. when the perception, memorization and reproduction of information occur sequentially and are links of one chain. Thus, the analysis and synthesis of the perceived material occurs and a holistic conceptual perception is obtained. This process is time-consuming and requires certain conditions - control processes in the form of repeated repetition [6] In accordance with the theory of J. Miller, at least 7 repetitions are necessary for highquality memorization of information [8].

At the same time, the modern generation of students perceive information not sequentially, but in the form of separate clips, bright mosaic fragments that do not have any conceptual connections between themselves, which prevents them from analyzing any phenomenon. This phenomenon is explained by the fact that images do not linger in memory for a long time and disappear almost immediately, giving way to others. As a result, students receiving new information are not able to concentrate, analyze it, highlight the main idea, establish logical connections and subsequently express their point of view. Thus, it is clearly seen that the clip-like thinking of modern students is expressed in the impossibility of a long concentration, the high speed of switching from one object to another, the inability to logically explain cause-effect relationships and apply theoretical knowledge in practice.

However, it should be said that in fact, the same phenomenon, as has been shown, also helps the younger generation to read and quickly receive information from a block of text - this is a very useful skill. In addition, computer games actually increase attention, awareness and quick decision making.

From the foregoing, a certain problem can be traced - what should be the training of modern students, and the following questions arise:

What methods and approaches are needed for training future teachers of foreign languages?

Do teachers need to invent a new technology for teaching students with clip thinking?

On the first question, as practice shows, the answer is obvious - it is definitely necessary to look for new approaches and methods in teaching students, since traditional ones can no longer completely solve the above problem. It is rather difficult to answer the second question, because in the time it takes to develop a new technology for teaching students with clip thinking, its further approval and official implementation, the problem can worsen or radically change and then the time and effort spent will be meaningless.

Perhaps the way out of this situation is in the postgraduate training of the teacher himself. In this regard, the concept of the European Union sounds more and more relevant, which says that a person must learn all his life. Nowadays, there is a wide range of opportunities for the teacher's self-education, which provides both communication in the scientific environment (scientific meetings, participation in conferences, seminars at various levels, etc.) and free access to Internet resources (information, educational materials, educational platforms, webinars and online conferences, etc.).

Adequate help in teaching future teachers of foreign languages can be textbooks published in those countries whose language is studied by students. Probably, these 
manuals have already been created taking into account the «clip nature» of modern students. They are built on the principle of providing educational information in parts of «units», each of which is dedicated to one fairly limited topic. There are no large volumes of lexical and grammatical material that needs to be learned; short texts consist of small paragraphs that are clearly separated from each other, which are accompanied by audio / video clips and vivid illustrations. All this, in general, helps students with clip thinking adapt. However, in order for the material obtained to be firmly assimilated in the long-term memory of students, additional materials are needed in the form of tasks, which will ensure the transition from clip thinking to traditional linear.

Modern educational platforms such as Moodle, Mirapolis, Uztest, iSpring, Edmodo, On-line simulators, TED-talk conferences, international youth forums can also be of great help. For students, this is a familiar environment. At the same time, when planning a lesson, the teacher must remember the specifics of clip students. All types of activities should be consistently alternated, logically complementing each other, but time should be allocated to each such type of activity, not more than 10 minutes.

In conclusion, it is necessary to emphasize once again the difference of the previous generation with digital thinking, which is characterized by multitasking, rationality and ability to think algorithmically, from students with clip thinking, who need new approaches in training and preparing them for future professional activities. It should also be noted that the basic peculiarities of training modern students - future teachers of foreign languages are the increasing importance of various exercises in daily teaching practice aimed at developing long-term memory, ability to concentrate, analytical skills, logical and critical thinking.

\section{References}

1. Бахтіна Г. П. Математика як «щеплення» проти «кліповості» інформації та «колажу» сучасного мислення. Вісник Луганського нац. ун-ту імені Т. Шевченка. Педагогічні науки. 2010. № 1(188). С. 144-155.

2. Маклюэн М. Галактика Гуттенберга: Становление человека печатающего. (The Gutenberg Galaxy: The Making of Typographic Man). Москва: Академический проект, 2005. 496 с.

3. Тоффлер Э. Шок будущего / пер. с англ. Москва: АСТ, 2002. 557 с.

4. Фрумкин К.Г. Клиповое мышление и судьба линейного текста. URL: http://nounivers.narod.ru/pub/kf_clip.htm.

5. Інформатизація освіти іїї наслідок-формування «кліпової» свідомості та «кліпового» мислення - крок уперед чи назад у медичній освіті? / Ярмола Т. І., Мохначов О. В., Ткаченко Л.А. [та ін.]. Матер. наук.-nрaкm. конф. «Удосконалення якості під- готовки лікарів в сучасних умовах». м. Полтава, 2016. С. 254-256.

6. Atkinson R.S., Schiffrin M. Human memory. A proposed system and its control process / H. Spence and I.T Spence (ed.) The Psychology of learning and motivation. N.Y., 1968. Vol. 2.

7. Clip Thinking - An Illness of the 21st Century. URL: https://www.forlearningminds.com/ article/clip_thinking

. George A. Miller. The Magical Number Seven, Plus or Minus Two. The Psychological Review. 1956. Vol. 63. P. 81-97.

9. Lancaster L.C., Stillman D. When generations collide: Who they are. why they clash, how to solve the generational puzzle at work. NY., 2002.

10. Rosen L. D. Me, My Space and I: Parenting the Net Generation. Palgrave Macmillan, 2007. 272 p.

Надійшла до редакиї 14.11.2019 